\title{
RESENHA DE GONZÁLEZ REY, F.L. (2011). El pensamiento de Vigotsky: contradicciones, desdoblamientos y desarrollo.
}

\author{
REVIEWS OF GONZÁLEZ REY, F.L. (2011). El pensamiento de \\ Vigotsky: contradicciones, desdoblamientos y desarrollo.
} RESEÑA DEL GONZÁLEZ REY, F.L. (2011). El pensamiento de
Vigotsky: contradicciones, desdoblamientos y desarrollo.

González Rey, F. L. (2011). El pensamiento de Vigotsky: contradicciones, desdoblamientos y desarrollo. México: Trillas

Mesmo que em língua hispânica, este livro de González Rey é uma preciosidade para todos os interessados, uma vez que ele não trata somente das teorias de Lev S. Vigotsky, mas, de certa maneira, da história da Psicologia Soviética.

A importância dessa obra reside no fato da dificuldade de o leitor não detectar, na primeira leitura, os diferentes momentos nela registrados, tendo em vista a profundidade do pensamento vigotskyano, o pouco acesso aos textos originais, a barreira do idioma e a fragmentação e deturpação das obras de Vigotsky, em alguns aspectos. Há, ainda, paradoxalmente, despreocupação em considerar os princípios de seus diferentes momentos, ou a preocupação em enfatizar apenas um destes momentos. Este livro, apesar de denso e com muitas informações, é de fácil leitura para os profissionais da área.

Diferentemente dos livros que tratam da teoria de Vigotsky de forma única, harmoniosa e linear, Fernando González Rey apresenta nuances ao longo da história e seu caráter contraditório, vivo e em desenvolvimento. Ele situa, sobretudo, os três momentos da obra vigotskyana, ocorridos ora por interferência política do país, ora por interferência do próprio desenvolvimento da ciência psicológica, naquele momento, e ora de acordo com os diferentes pensamentos desenvolvidos por ele mesmo.

Este livro de González Rey está dividido em cinco capítulos e mais o prefácio. O primeiro capítulo trata dos primórdios da Psicologia Soviética, antes mesmo da Revolução de Outubro, do contexto do surgimento da teoria de Vigotsky e do significado da primeira parte de sua obra. No segundo capítulo são tratados os dois outros momentos da obra Vigotsky, quando são tecidas também algumas reflexões a respeito de suas propostas metodológicas. No terceiro, ainda é abordado o contexto da teoria de Vigotsky, e apontados os seus principais contemporâneos, os quais também participaram do desenvolvimento da Psicologia Soviética. São apresentadas as obras de S. L. Rubinstein, de B. G. Ananiev, de D. N. Uznadze, dentre outros, e tratadas as semelhanças e as diferenças das ideias desses autores com a teoria de Vigotsky.

O quarto capítulo versa acerca do desenvolvimento e das contradições da obra de Vigotsky, e da crítica à teoria da atividade de $\mathrm{A}$. N. Leontiev, esta última, inclusive, entre alguns seguidores de Leontiev. Por último, no quinto e mais longo dos capítulos, González Rey dá continuidade à crítica à teoria da atividade e à obra de Vigotsky, apresentando os novos desenvolvimentos a partir da teoria elaborada por ele mesmo, fazendo isso sobretudo com a teoria da subjetividade que, conforme ele teoriza, é um dos desdobramentos e desenvolvimentos possíveis do legado deixado por Vygotsky (o marco da nova Psicologia Histórico-Cultural). Neste capítulo, dentre outros assuntos, são abordadas as críticas dos anos 70, do século XX, às teorias da atividade e à obra de Vigotsky como um todo, e a introdução do tema da comuni- 
cação e suas consequências na Psicologia Soviética. Entretanto, os temas mais importantes deste capítulo referem-se à questão da subjetividade na Psicologia Soviética - suas bases, desenvolvimento e contradições - e ao desenvolvimento atual do tema, propostos por González Rey, com desafios e perspectivas, aspectos que serão abordados um pouco mais ao final desta resenha.

Algumas das características da obra de Vigotsky são apresentadas por González Rey mostrando-a em seus três momentos. O primeiro momento, de 1915 a 1928, foi marcado, principalmente, pela publicação de seu livro Psicologia da arte, época em que Vigotsky estudou a relação entre cognição e afeto, questões da fantasia e da imaginação, e o caráter gerador das emoções humanas. O segundo momento, de 1928 a 1931, foi um período mais distinto em face dos outros quando, de acordo com o autor, existiu a afirmação da teoria histórico-cultural sobre a psique. Neste período Vigotsky estudou o desenvolvimento das funções psíquicas superiores, trabalhando, então, os conceitos de signo, ferramenta, mediação e interiorização. Este período, conforme González Rey, recebeu críticas em vista do estreito conceito do social e da cultura, por não considerar a comunicação em seus trabalhos e pelas consequências passivo-reprodutivistas do ensino na União Soviética. Enfim, esta foi uma fase mais determinista, segundo o autor, quando foram desconsideradas as emoções nas funções psíquicas.

No terceiro e último momento dessa obra, de 1928 a 1934, houve, de acordo com González Rey, o retorno a alguns aspectos de seu primeiro momento, tais como emo- ções, arte e fantasia, os quais foram associados às questões de sentido e de vivência, desprendendo a linguagem e a cognição do lugar central da Psicologia, o que deu lugar ao desenvolvimento futuro do tema subjetividade.

À guisa de conclusão, ressalta-se que González Rey não somente estuda de forma primorosa os diferentes momentos da obra de Vigotsky, mas também se propõe ao desenvolvimento posterior desta psicologia, como proposta de continuidade ao legado de Vigotsky, com o estudo da teoria da subjetividade, na Psicologia Histórico-Cultural. $\mathrm{Na}$ teoria de González Rey o humano se forma e se desenvolve nas histórias de sua vida e da sociedade em que vive. $O$ emocional nas funções psíquicas é outro aspecto importante na teoria da subjetividade. Nele, também, há os efeitos dos acontecimentos da vida e da subjetividade social, na subjetividade individual, mas não de maneira imediata, mas com independência relativa. Há a integração do social e do individual em um novo nível qualitativo e a pessoa passa a ser um elemento ativo da organização social, rompendo a dicotomia entre o social e o individual.

Desta forma, somos brindados, com a leitura deste livro, não apenas com a história da Psicologia Soviética, com o aprofundamento da teoria de Vigotsky e dos três momentos de sua obra, mas também com a teoria de González Rey, que pode ser considerada como uma continuação da teoria de Lev Vigotsky naquilo que muito interessa àqueles que consideram o homem na sua individualidade e no social, qual seja, a teoria da subjetividade.

\section{Sobre a autora}

\section{Maria Eleusa Montenegro}

Pedagoga, mestre e doutora em Educação (área de concentração em Psicologia da Educação) pela UNICAMP, e pós-doutora em Educação pela UnB. É professora aposentada pela Universidade Federal de Goiás (UFG) e atualmente é professora do Centro Universitário de Brasília (UniCEUB). 